\title{
THE COPPENAME KWINTI: NOTES ON AN AFRO-AMERICAN TRIBE IN SURINAM
}

I History and Development

Kwinti origins and settlement-Population size-Language, isolation and obscurity.

II Organization and Ideology

Foreign affairs - Internal affairs - Clan and lineage - Marital relations Christianity - Native polytheism

III Culture Change and Viability

Population and culture - Village economy - Ecology and acculturation Adaptations - Factors in future viability

References

The ethnographic data for this report were collected during a ten-weeks' pilot study which my wife Kathleen and I conducted among the Bitagron Kwinti in the summer of 1973. This research was supported by National Science Foundation grant No. GS-38142, and by a Faculty Research grant from CSUF. Address of author: California State University, Fresno.

Ir. F.C. Bubberman, The Director of 's Lands Bosbeheer (Surinam's Forestry Service), has been of inestimable importance to my understanding of Kwinti culture. Not only did he physically introduce us to the people of Bitagron, but he freely and enthusiastically shared the fruits of his personal research into the history of Bush Negro migration and settlements. I am indebted to Ir. Bubberman and Drs. P.A. Teunissen, the goverment biologist at Raleigh Falls at the time of our research, for their information about Bush Negro ecology.

\section{HISTORY AND DEVELOPMENT}

The Kwinti constitute the smallest and least known of the recognized Bush Negro societies, although their territory is theoretically subject to the authority of the Matuari paramount chief. The Coppename River branch of the Kwinti achieved the furthest western penetration by an independent Bush Negro tribe. 


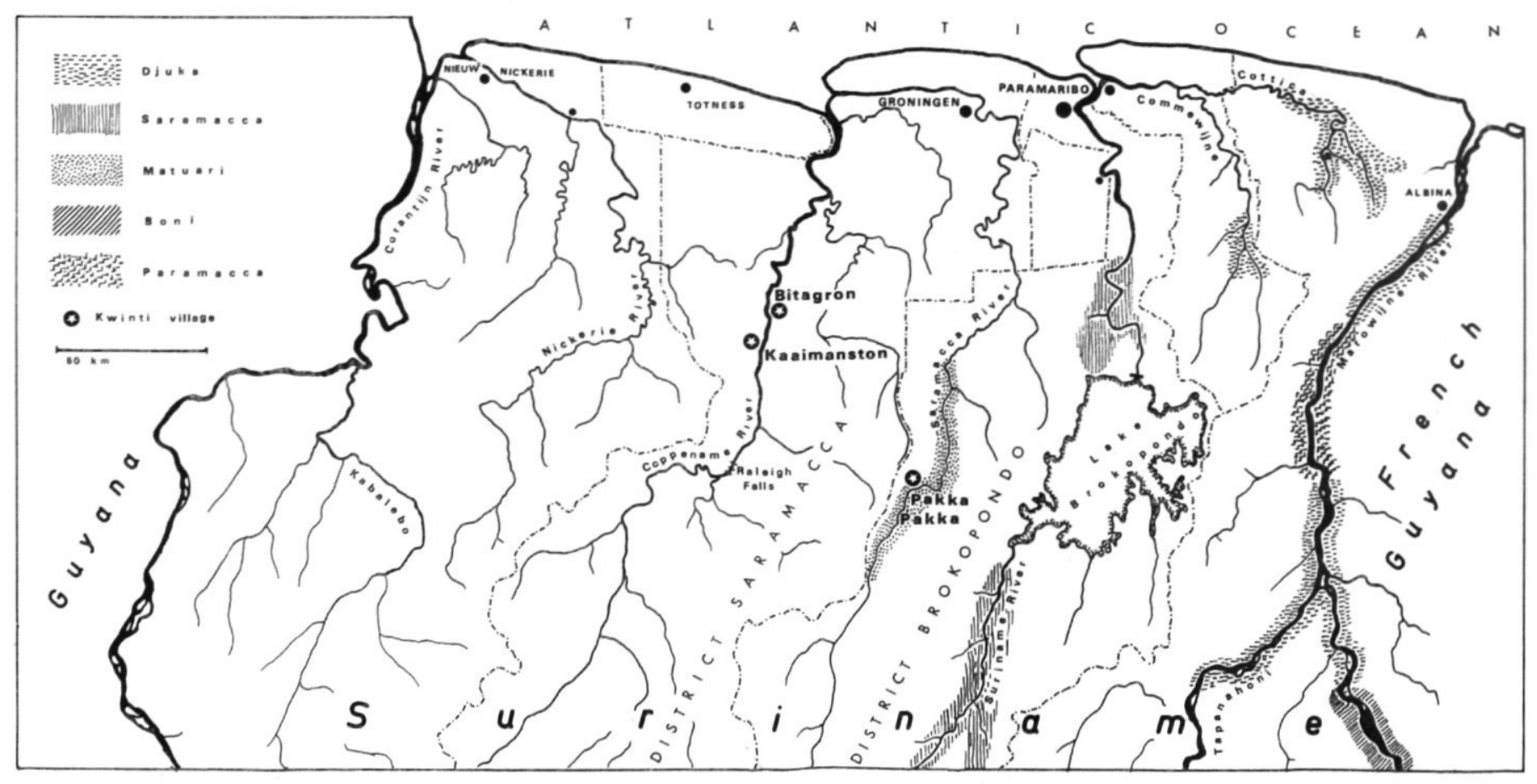


The term 'Bush Negro' refers to a culture complex indigenous to the rain forests of Surinam in South America: that is to say, to the New World's only Afro-American tribal area. It consists of an estimated 35,000 descendants of Maroons, rebel slaves who established themselves in the interior of Surinam during the 17th and 18th centuries. (For a general introduction to the culture area, see Van der Elst 1970).

At present, the Bush Negroes are organized into six tribes and an unknown number of lesser independent lineages. The largest tribe is the Djuka, whose villages may be encountered along any of Surinam's major rivers, but whose tribal homelands are along the Marowijne River and its Tapanahoni branch, the nearby Cottica River, and the Tempati Creek (Köbben 1966, 1967, 1968, 1969; Thoden van Velzen 1966 a, b; Van Wetering 1973). Sharing the easternmost sector of Surinam are two smaller tribes: the Boni or Aluku occupy both banks of the Lawa branch of the Marowijne, and thus are also found in French Guyana (Hurault $1956,1957,1961,1965)$; the Paramucca live in the center of the Djuka's Marowijne territory (Lenoir 1973). The Saramacca, who constitute the second largest tribe, have a domain which extends north and south of Lake Brokopondo on the Suriname River (Herskovits 1929, 1930; Herskovits \& Herskovits 1934; Price 1969, 1970 a, b, 1973). The Matuari or Matawai of the Saramacca River are the largest tribe to have been converted to Christianity.

\section{Kwinti Origins and Settlement}

The Kwinti occupy three villages along two rivers. The Saramacca River Kwinti live in Pakka Pakka, isolated in the middle of a string of Matuari villages. The Coppename River Kwinti form the westernmost outpost of the Bush Negro culture area. They live some 70 kilometers northwest of Pakka Pakka in Kaaimanston, on the left bank of the Coppename, and almost $20 \mathrm{~km}$ further downriver in Bitagron on the Coppename's right bank.

Until early in this century, a jungle trail connected the Coppename Kwinti with the Saramacca branch. Few people now remember the location of that trail, and no living Kwinti has walked along it. The fact that the jungle has been allowed to reclaim the path attests the present disinterest in communication between the two areas. The Coppename Kwinti consider Pakka Pakka to be a second-rate Matuari village, and its existence plays no part in their life. This report is restricted to the culture of the Coppename Kwinti. 
There are detailed but conflicting legends about the origins of the Kwinti. One holds that their ancestors escaped from Berbice (a colony in what is now Guyana) down the Corantijn River, which they occasionally refer to as the 'Kwinti Liba.' They fled up the Nickerie, a river system which connects the Corantijn with the Coppename, and lived there for a very long time. Later they moved deeper inland out of fear of the military patrols, and built a village called P'isi (Pleasure) where no one ever died. A scarcity of marriageable people eventually drove them on again, to settle among the Matuari. The Matuari enslaved and persecuted them, and so one Kwinti chief, Captain Alamu, led his people out of bondage to the Coppename.

If the Kwinti indeed moved eastward from Berbice, they are the only Bush Negroes to have done so. When the slave revolt of Berbice ended in 1687, the Indians made a treaty with the planters, and thereafter killed or returned all Maroons. In effect, there have been no successful escapes from the colonies Berbice, Demerary, and Essequibo (areas in what is now Guyana). This is evidenced by the fact that no Bush Negro societies have ever existed there, as far as is known. The implication of this origin myth is that the ancestral Kwinti first settled along the Corantijn before the whites or blacks had colonized it, and before the Indians sealed the area. That, if true, would mean that this is one of the oldest black societies in the Americas.

The only support for this position, however, lies in the existence of a number of Indian groups in Nickerie which, according to even the earliest descriptions of the colony, have some African physical characteristics. These so-called 'Karboegers' (after the Dutch karbonkel, a dark-red ruby) still live in the northwestern jungles of Surinam. But until the middle of the last century, no Afro-Americans were known to reside in that area.

Quite at variance with this legend is a second folktale which has the ancestors escaping westward from Paramaribo, avoiding all other people, and crossing rivers and creeks by raft rather than by boat. The runaways finally settled in the forest East of the Saramacca River. When their village became strife-ridden, the population split into three groups: the Kwinti went West, the Paramacca went East, and the Dudo lo (clan) returned to their master. The Kwinti then built a new village called Prisiri or P' isi, which they later left to join the Matuari.

If there is a factual core in this account, then the ancestral Kwinti escaped after the 1760 's. With the treaties of that decade, 
the Djuka, Saramacca, and Matuari began returning Maroons to the whites for the bounties they brought. This sealed much of the Surinam bush, just as the Indians of Berbice had sealed Guyana a century earlier. Before 1760 there would have been no point in "avoiding all other people." The Lowland Indians posed no threat to Surinam's runaway slaves, and the black tribes still accepted recruits. The item about rafts further indicates that the early Kwinti lacked forest technology, and we may assume that they were city Creoles, not African 'salt-water' slaves.

Again only a single bit of external evidence supports this version: the Paramacca also claim to have lived in one village with the Kwinti (Lenoir 1973, personal communication). It must be noted that the Kwinti unanimously reject the idea that they learned their bushcraft from Indians. They deny that their ancesters ever lived with Indians, and though they were apparently fascinated by the idea of dark-skinned Indians, they insist that they had never heard mention of Karboegers before I visited Bitagron. Nevertheless, they maintain that they were adept Bush Negroes before they ever met the Matuari.

Finally, some believe that the leader of the ancestral Kwinti was the African Koffie, an older brother of Bonni, the founder of the Boni (or Aluku) tribe. Koffie and his people had lived in the forests just south of the plantation area for some time before they convinced Bonni to run away. Bonni's father was white, and only when it became clear that this conferred no advantage did Bonni begin to plot a massive uprising. In the turmoil which followed, the brothers were separated. Koffie's people escaped to the West, hotly pursued by the Army, to become the Kwinti. Bonni's group fled through Djuka territory in and out of French Guyana, until Bonni was murdered by the Djuka. The two groups never had the chance to unite.

If this myth contains any truth, it means that the Kwinti date from around 1765, because Bonni escaped just after the peace treaties, and fought battles with Fourgeoud's 'Red Berets' in 1771. This fits well with the dates of the previous version, and explains incidentally that the ancestral Aluku learned their woodcraft from the African-led ancestors of Kwinti. But if the Kwinti and Boni have blood ties, and the Kwinti and Paramacca are related, it would follow that the Paramacca are related to the Boni. Lenoir (1970) had noted that the relations between these two tribes are much more amicable than those between the Paramacca and the Djuka, their other neighbors on the Marowijne 
River. It is not known whether the Boni recognize kinship ties with the Kwinti.

It is possible, of course, that all three accounts are true. Maroons from Berbice may have developed or adopted a jungle culture. They may have been joined later by one or more small groups of more recent runaways who had avoided the 'Treaty Tribes,' the Saramacca and the Matuari, out of fear of being re-enslaved.

The appeal of this position lies in the fact that it accounts for the disagreements among the three versions of the origin myth which the Kwinti themselves report. It may also help clarify the many divisions and schisms which mark Kwinti history, and explain the relative poverty of Kwinti culture. But it is unlikely that this 'inclusivist' theory would be acceptable to the Kwinti elders, for each of them holds to one of the 'exclusivist' versions.

Historical data on Kwinti derivations are scarce, but in the future some insight may be gained from Pakka Pakka and Matuari folklore, from the Colonial Reports of the Commissioners of District Saramacca, and from the accounts of the missionaries of the Evangelical Brethren Society who brought Christianity to the Matuari and the Kwinti. It has been established that sometime during the nineteenth century, probably after the repeal of slavery in 1863, the Kwinti migrated eastward from a now-forgotten area between the Coppename and Saramacca rivers. They were allowed to settle among the Matuari, who exposed them not only to their own form of Christianity, but to witchcraft accusations and to second-class citizenship. Endless friction between the two groups moved Governor Tonckens around 1883 to grant one Kwinti village chief, the legendary Alamu, the right to settle on the Coppename while remaining under the paramount chieftancy of the Matuari Granman. (This ultimate supremacy of the Matuari Granmans continues to this day, much to the dissatisfaction of the Kwinti). The Coppename River basin was entirely unpopulated at that time, except for its Tibiti tributary where some Djuka loggers had built camps. Alamu and a small group of his followers accepted a village site suggested by the Djuka lumberjacks, and built a hamlet called Coppencrisie, for 'Coppename Christians.' Because of internal strife this village was abandoned and its people moved upstream to two new locations: Kaaimanston and Bitagron. The exact date of this population shift is not known. Each village today claims seniority, and since 
none of the elder Kwinti knows his own age, the dates are not recoverable. However, a comparison of their memories indicated that people who appear to be in their 60's do not remember Coppencrissie, while the very aged (80- tot 100 -year-olds) were all born there or in Kaaimanston. A Dutch survey expedition up the Coppename in 1901 records Kaaimanson and Coppencrissie, noting that both were thriving (Bakhuis 1902). This sole record of the Kwinti does not mention Bitagron. Coppencrissie therefore must have been deserted after November 23, 1901, the date when the last member of the expedition left there (Bakhuis 1902, p. 138). Bitagron did not become a village until after Alamu left Coppencrissie. It seems likely, therefore, that these events occurred between 1902 and the First World War.

For some years beginning in the 1930's, there was a small settlement named Tjakkatjakkaston on the left bank of the Coppename about $15 \mathrm{~km}$ North (downriver) of Bitagron. It never became an independent village, and has long been deserted. Although many maps still show it, the jungle has reclaimed Tjakkatjakkaston as utterly as Coppencrissie.

\section{Population Size}

The sizes of the two remaining villages have changed drastically. Kaaimanston used to be the dominant village, and was so much larger than Bitagron that when the government decided to build a school on the Coppename, it was built in Kaaimanston.

The village today has about sixty buildings including sheds, but many of these are in disrepair and most houses are deserted. We never counted more than 30 people there at any one time, excluding the Bitagron children who attend school in Kaaimanston.

Bitagron, however, appears to be flourishing. A census taken on July 12,1973 , enumerated 143 persons actually present in the village: 32 men, 36 women, 33 boys, and 42 girls. Another 17 persons were accounted for as working and living in Paramaribo, and that day seven more were staying in their gardens or working in the vicinity.

There are 92 buildings in the village (not counting the Catholic Church and the bigi sangga, the meeting hall): 51 s'ibi oso or sleeping houses of which seven were deserted and six were being built, 27 kuku oso or kitchens, 9 isanga or work sheds, 2 kangsia or storage sheds, and 3 afkodrai oso or kunu houses. Several men now living in Kaaimanston are building houses in Bitagron. 
An unknown number of Kwinti have left the Coppename area more or less permanently. Most of these are people from Kaaimanston. Genealogies indicate that they probably number less than 50 adults. Many of them emigrated many years before the road was built.

Of the 200-225 permanent residents of the Kwinti villages, some 15 are members of the Djuka and Saramacca tribes. They are either married to Kwinti, or have a Kwinti father (having a Kwinti mother would make one a Kwinti, since descent is matrilineal). Although there are other Djuka and Saramacca working in Heidoti, a camp of the Geological and Mining Services on the Coppename about $30 \mathrm{~km}$ downriver from Bitagron, there appears to be no interaction between the villages.

\section{Language}

Elder Kwinti often bemoan the debasement of the old, true Kwinti language into a dialect of Taki Taki (Sranan, the lingua franca of Surinam's many ethic groups). The two languages do have the same grammar, and their vocabulary differences are being lost. Children generally use old and new terms interchangeably, and intrusive traits and concepts usually carry Dutch or Sranan labels. For example, when the new village chief of Kaaimanston told his friends how he had passed his driver's license examination in Paramaribo, he was completely understandable to the ethnographer because such terms as automobile, motorcycle, brake, wheel, tire, pump, windshield, headlight, transmission, left-hand traffic, and driver's license all were Dutch terms, pronounced with the typical Taki Taki and Kwinti exchange of certain stops for certain fricatives.

There are few remnants of ceremonial languages. When the Kromanti warrior spirit named Okwasyashi dabi yankama okonto bifo kwayani takes possession of his medium, he speaks 'Dipi from Africa.' When Basyempre usu, another Kromanti, takes possession of his own medium, and the two supernaturals talk together, the Kwinti all seem to understand their jokes and conversation. Okwasyashi further claims that the Coppename Kromanti can understand all other Kromanti in Surinam, although he insists that each river has its own variety of Kromanti, just as it has its own variety of Ningre Tongo, Bush Negro Language. Apparently, then, Dipi is not very different from standard Kwinti. 
We witnessed no attempt to use a secret or private language, in the sense that Hurault (1961, p. 68) reports for the Boni, to confuse outsiders or people of other generations. People who were possessed by supernaturals other than Kromanti, always spoke in standard Kwinti. Certain key terms in many of the religious rituals are 'Old Kwinti', but the interaction between supernatural, priest, and congregation is in normal speech.

\section{Isolation and Obscurity}

Except for a brief and abortive attempt by Dutch farmers around the year 1800 to settle near its mouth, the Coppename sector of Surinam has been deserted by all but the Kwinti since the British and Dutch defeated the Carib and Arawak Indians in the late 17 th century. Even now, there are few Indians or other ethnic groups living in the area. The human population of the vast territory drained by the Coppename does not approach 1,000.

Until very recently, water routes formed the only link between Kwinti land and the City. The Bakhuis expedition reached the area by traveling from Paramaribo through the Saramacca Canal, along the Wanika Creek and down the Saramacca River to reach the Coppename (Bakhuis 1902, p. 23). Kwinti wishing to visit the capital had to use the same route, or follow the Atlantic Coast for almost $100 \mathrm{~km}$ between the Coppename and the Suriname rivers. The fact that the Bakhuis report is the only previous account mentioning the Kwinti, indicates something of the past isolation of the area, an isolation which continued until the 1969 opening of the road which now connects Bitagron to the population centers on the Suriname River.

Nevertheless, the cultural isolation of the Coppename Kwinti has been overrated. In spite of the tremendous energy which such a journey required, all the elderly men except the head captain claim to have taken a few trips to town before the road was built. The age of some of the tools and utensils in the villages bears this out. And some of the shotguns the Kwinti hunt with must have been manufactured in the 1920's. Furthermore, emissaries of the Western world have visited the Kwinti. Every few years the District Commissioner travels by boat from Groningen to the area. The Evangelical Brethren Society (the EBG) have maintained a teaching missionary in Kaaimanston for decades. The present couple has lived there since the late 1950's. Catholic 
priests have visited the Kwinti periodically since the 1920's. Ubiquitous gold teeth and fillings attest to the visits of the government's doctor-dentist who stays for a few days every year. And although the Kwinti practiced no trade with their Matuari neighbors, not even in such necessities as salt and hardware, they report never to have suffered scarcities of any kind.

The idea of their present day isolation is even more exaggerated. Few people in Paramaribo knew that a tribe named Kwinti existed. Fewer still have actually traveled in the Interior, and the Coppename is as remote and alien to most Surinamers as the Amazon River. But one finds no pristine primitives in Kwinti land. The ferrite road of the Forest Service which reached Bitagron in 1969 had made it possible for people to hitchhike to town on vehicles owned by traders, tourists, or the State. And they do so often, to go shopping, to seek medical aid, or sometimes to seek work.

There are three trading parties who take fish and game in exchange for money, bottled beer, and anything else the Kwinti want transported from town. A Hindustani trading crew comes in at least twice a week. A Creole-owned truck stops off every five or six days. A Buru (white native farmer) visits irregularly. The traders have supplied Bitagron with three freezers and bring ice for these chests on every trip. Bitagron's two main winkis (stores), which are owned by village captain Boomdijk and by Basia Awani, stock a surprising variety of goods ranging from canned foods, soft drinks and tobacco, to shotgun shells, toilet paper and aspirin.

Raleigh Falls is the headquarters of a relatively new national park some $60 \mathrm{~km}$ upstream from Kaaimanston. As it becomes better known, more and more tourists from as far away as the USA and Europe take the road to Bitagron, and wait there for the canoes from the Falls to take them upriver. Their multi-ethnic and multi-racial groups of up to 20 people descend on the village about once a week.

The Geological Survey (Dienst Bodemkartering) has built a service complex along the access road to the village, just off the main road and less than 500 yards from the first huts of Bitagron. A couple of Creoles live there and maintain the facilities for the various crews which are exploring the area.

Except for the first two weeks of our stay there, not a day went by without at least one vehicle entering the village. In this sense, 
Bitagron is far from isolated. Admittedly the traders and tourists and other passers-through spend very little time in the village. Nevertheless, their effect is felt. The Saturday night dances in the bigi sangga, the meeting hall, draw all the young and middle-aged in the neighborhood. Those who do not dance, listen to the drumming, or just visit and drink. Many of the strangers bring their own women, and the idea of fashion is beginning to intrigue the younger generation. The bigi sangga also doubles as a sleeping hall for the work crews of Bruynzeel (a lumber corporation), Raleigh Falls, and various governmental agencies while they await canoe transport. During their brief occupations of the hall they interrupt the normal flow of life by playing loud music in the middle of the night, by keeping the store open during abnormal hours, or just by being conspicuous in the middle of the village. A few of these men are Bush Negroes, and one or two of them have become the husbands of Kwinti girls.

Most of the young and middle-aged Kwinti have spent some time working on road crews, for the forest service, with geological survey crews, or the lumber companies. Some of them have worked or even gone to school in Paramaribo for periods of up to twelve years. The children, of course, are all learning to read and write Dutch in the Kaaimanston school, and this year for the second time, the teacher took the whole school (some 25 or 30 children) on a two-day trip to the big city.

As a result of all this interaction and travel, there are various modern conveniences in the village. Every family has a large number of aluminum pots and pans. Almost all men own shotguns (single-shot 12 and 16 gauge Stevens or Topper models). Many people own battery-powered radios and record players. Kapitein Boomdijk has a gasoline-powered generator so that his store and his son's house have electric lights. There are two refrigerators, both of which run on petroleum, and are used only to chill beer. And finally, there are seven outboard motors in Bitagron, and one in Kaaimanston. It does not seem possible that all these riches were acquired in the four years since the road opened.

It is safe to conclude, therefore, that though the West may long have been ignorant about the Kwinti, the Kwinti have long been familiar with the West. Obscurity cannot be equated with isolation.

(To be continued.) 